\title{
A centenarian extraordinaire
}

\author{
Peter Tyrer
}

\section{Summary}

Henry Rollin, a distinguished Member, Fellow and now Honorary Fellow of the Royal College of Psychiatrists, has attained his 101st year. The achievements of this remarkable man are described and speculations made about the reasons for his longevity and his plans for the future.

\section{Declaration of interest}

P.T. is Editor of the British Journal of Psychiatry.
Official predictions suggest that between 10 and $17 \%$ of children born today across the world will reach the age of 100 . This is a mind-blowing statistic and I will leave it to later editors to puzzle how to celebrate the works of at least 1000 centenarian psychiatrists in our journals in 2111. But - stuck as we are in the era of old-fashioned mortality - we have only one who has reached this landmark, Henry Rollin. (Perhaps there are others and the Royal College of Psychiatrists would like to know of them if they care to get in touch.) But what a centenarian to start off with! I doubt that any in the near future will be able to match Henry's energy and productivity. This is not to decry the achievements of many others of advanced age, such as Irving Gottesman and Tim Beck in the USA, and Herman van Praag in The Netherlands, but they have some years to go to reach their centuries. One of our Honorary Fellows, Sir George Godber, recently died at the age of 100 and, although he had a highly productive mind, he moved to Cambridge in his latter years to benefit from its excellent medical care for the elderly.

But Henry is not thinking in these terms. He has not stopped since the age of retirement; he has accelerated into overdrive. The notion of slipping gently into old age could never apply to him, and just a brief reminder of Henry's life in the past 40 years illustrates this. Not for him a fixed routine of existence, supported by a diet rich in the fruits of longevity and a lifestyle free of stress, but instead the rugged highway of someone decades younger. This has included a highly successful marriage (Henry was a late starter here) leading to fatherhood, a 10-year stint as honorary librarian of the Royal College of Psychiatrists, a new career as consultant forensic psychiatrist to the Home Office, attempted murder (of, not by, Henry) and a busy career in medical journalism. The attempted murder was carried out by a patient Henry was assessing at Brixton Prison in London. The assailant had been a professional boxer and my only surprise on reading about this was that Henry had not reacted to him in kind, as he too was a boxing champion in his youth. Henry's journalism has included work on many journals. This has included being the obituary editor of The Psychiatrist, a task which he has described as a 'melancholy job, ${ }^{1}$ but which I suspect has been of more interest to him than many as he must have known personally as juniors many of those who have died. We have also had the consequences of a prescient invitation from the late Hugh Freeman, former editor of the British Journal of Psychiatry, to write a column entitled 'A Hundred Years Ago'. The first in this series, giving excerpts from medical journals a century ago, was published in $1985,{ }^{2}$ and we have had many titbits since that help to put our present concerns over psychiatric practice into a better context.

Henry has also been a researcher into mental illness and must have been amazed at both how much has changed and how much has remained the same in the past two generations. One of his first papers on personality and physical features was published in
$1942 ;^{3}$ we are still publishing similar papers 60 years later, and although our interest has moved from the external to the internal, ${ }^{4}$ our fundamental understanding is not that much greater than in 1942. Henry has also sent a paper this year that he hoped would be published in the British Journal of Psychiatry. Much as I would like it to be published, it is a historical paper that has not been approved by our army of hard-nosed reviewers as it is not considered to be relevant to current practice. But it is still fascinating. 'How the Enlightenment penetrated the gloom of Victorian alienism' is its title and it refers to what Henry calls the 'magic triad'. Nowadays, we speak of the 'golden triangle', the cities of Oxford, Cambridge and London, which together make up the largest part of medical and psychiatric research in the UK. Henry is not, however, discussing the south of England; the magic triad for research and advance in mental illness in Victorian England were the northern towns of Leeds, York and Wakefield, with Hack Tuke and James Crichton-Browne as their standard-bearers. The paper includes many Rollinisms: 'The Retreat, York, is to the history of British psychiatry what the York Minster is to the history of mediaeval church architecture', and 'Crichton-Browne's crowning achievement was to decriminalise and sanitise the unsavoury reputation of asylums. He did this by tearing down the prison-like walls surrounding so many of the patients' blocks, so restoring the original park-like grounds'. Henry ends his paper, 'Sir James Crichton-Browne died in 1938, aged 97, the last of the great Victorians.' I sometimes think that Henry Rollin is really another great historical figure, but an Edwardian; he has spanned the past 100 years like a giant with one foot in the past and the other in the present, and exhorts us not to forget what hard-won gains our forefathers have made.

But what of the next 100 years? I do not know what is in Henry's mind, but I am sure he is actively organising something of importance. I can only stand aside in wonder and surmise:

Now Henry is 100

I have often wondered

What next is in his plan

Our new-born Superman.

Over to you, Henry.

Peter Tyrer, FMedSci, FRCPsych, Centre for Mental Health, Department of Psychological Medicine, Imperial College (Charing Cross Campus), St Dunstan's Road, London w6 8RP, UK. Email: p.tyrer@imperial.ac.uk

First received 23 Aug 2011, final revision 26 Aug 2011, accepted 31 Aug 2011

1 Rollin HR. In conversation with Alan Kerr. Psychiatric Bull 1999; 23: 286-90.

2 Rollin H. A hundred years ago. Br J Psychiatry 1985; 146: 228

3 Wolfe $\mathrm{C}$, Rollin HR. The hands of Mongolian imbeciles in relation to their three personality groups. J Ment Sci 1942; 88: 415-8.

4 Raine A, Lee L, Yang Y, Colletti P. Neurodevelopmental marker for limbic maldevelopment in antisocial personality disorder and psychopathy. Br J Psychiatry 2010; 197: 186-92. 